OAK RIDGE NATIONAL LABORATORY

LocknEEs ma

\section{RECEIVED \\ MAY 231996 \\ OSTI}

\title{
Review of Uranium
}

Bioassay Techniques

J. S. Bogard 
This report has been reproduced directly from the best available copy.

Available to DOE and DOE contractors from the Office of Scientific and Technical Information, P.O. Box 62, Oak Ridge, TN 37831; prices available from (423) 576-8401, FTS 626-8401.

Available to the public from the National Technical In'ormation Service, U.S. Department of Commerce, 5285 Port Royal Rd., Springfifld, VA 22161.

This report was prepared as an account of work sporisored by an agency of the United States Government. Neither the United States Government nor any agency thereof, nor any of their employees, makes ariy warranty, express or implied, or assumes any legal liability or responsibility for the accuracy, completeness, or usefulness of any information, apparatus, product, or process disclosed, or represents that its use would not infringe privately owned rights. Reference herein to any specific commercial product, process, or service by trade name, trademark, manufacturer, or otherwise, does not necessarily constitute or imply its endorsement, recommendation, or favoring by the United States Government or any agency thereot. The views and opinions of authors expressed herein do not necessarily state or reflect those of the United States Government or any agency thereof. 


$$
\text { ORNL--6857 }
$$

ORNL-6857

\author{
Assessment Technology Section \\ Health Sciences Research Division
}

\title{
Review of Uranium Bioassay Techniques
}

\author{
J. S. Bogard
}

Date Issued - April 1996

Prepared by the

OAK RIDGE NATIONAL LABORATORY

Oak Ridge, Tennessee 37831-6285

managed by

LOCKHEED MARTIN ENERGY RESEARCH CORP.

for the

U. S. DEPARTMENT OF ENERGY

under contract number DE-AC05-96OR22464 



\section{CONTENTS}

LIST OF FIGURES $\ldots \ldots \ldots \ldots \ldots \ldots \ldots \ldots \ldots \ldots \ldots \ldots \ldots \ldots \ldots$

LIST OF TABLES $\ldots \ldots \ldots \ldots \ldots \ldots \ldots \ldots \ldots \ldots \ldots \ldots \ldots \ldots \ldots \ldots \ldots$ vii

ACKNOWLEDGMENTS $\ldots \ldots \ldots \ldots \ldots \ldots \ldots \ldots \ldots \ldots \ldots \ldots \ldots$ ix

ABSTRACT $\ldots \ldots \ldots \ldots \ldots \ldots \ldots \ldots \ldots \ldots \ldots \ldots \ldots \ldots \ldots \ldots \ldots \ldots \ldots$

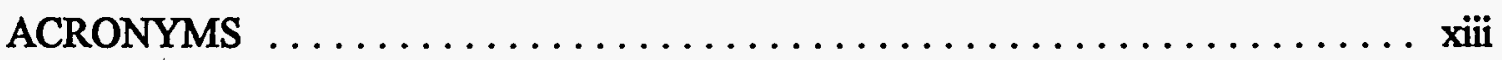

ANALYTICAL CHEMISTRY OF URANIUM $\ldots \ldots \ldots \ldots \ldots \ldots \ldots \ldots$

UV - VISIBLE SPECTROPHOTOMETRY $\ldots \ldots \ldots \ldots \ldots \ldots \ldots \ldots \ldots 2$

FLUOROMETRY AND PHOSPHOROMETRY $\ldots \ldots \ldots \ldots \ldots \ldots \ldots \ldots 2$

METHODS BASED ON MEASURING ALPHA RADIOACTIVITY $\ldots \ldots \ldots \ldots 5$

NEUTRON IRRADIATION METHODS $\ldots \ldots \ldots \ldots \ldots \ldots \ldots \ldots \ldots \ldots$

MASS SPECTROMETRIC TECHNIQUES $\ldots \ldots \ldots \ldots \ldots \ldots \ldots \ldots \ldots$

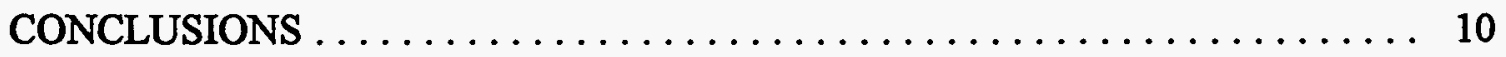

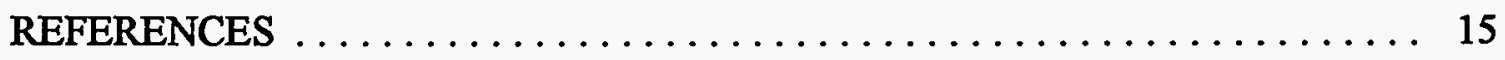





\section{LIST OF FIGURES}

1 Coefficient of variation for fluorometric determination of uranium in water

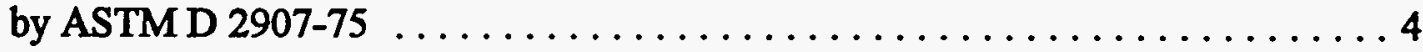

2 Comparison of analytical results for ${ }^{235} \mathrm{U}$ in urine: ICP-Mass spectrometry and delayed neutron analysis

3 Comparison of analytical results for ${ }^{238} \mathrm{U}$ in urine: ICP-Mass spectrometry and delayed neutron analysis 


\section{LIST OF TABLES}

1 Reported EML interlaboratory comparison results (ng/mL total uranium in urine)

2 Uranium concentration detection limits for $\alpha$-particle spectrometry using silicon detectors

3 Comparison of analytical results for uranium in urine: ICP-Mass spectrometry and delayed neutron analysis

4 ICP-MS analytical results for uranium in biological materials 12

5 Reported uranium measurement levels in excreta and tissues for several analytical techniques 



\section{ACKNOWLEDGMENTS}

This report was prepared initially as part of a publication on uranium by Scientific Committee 57 of the National Council on Radiation Protection and Measurements. It is being published separately as ORNL-6857 to enhance its availability to the community of analytical chemists interested in strategies for quantitatively analyzing uranium in human excreta and other biological matrices.

Valuable reviews and comments were provided at different stages in the preparation of this report by $M$. Thein, M. Hotchandani, and R. L. Ferguson (retired) of the Oak Ridge National Laboratory (ORNL) Office of Radiation Protection; J. R. Stokely, Jr., F. F. Dyer, and J. W. Wade of the ORNL Chemical and Analytical Sciences Division; and Tom J. Whitaker of Atom Sciences; Inc., Oak Ridge, Tennessee.

The author wishes to thank K. S. Brown for her editorial assistance in the preparation of this manuscript, and the Health Sciences Research Division of Oak Ridge National Laboratory for supporting this work. 



\begin{abstract}
A variety of analytical techniques is available for evaluating uranium in excreta and tissues at levels appropriate for occupational exposure control and evaluation. A few (fluorometry, kinetic phosphorescence analysis, $\alpha$-particle spectrometry, neutron irradiation techniques, and inductively-coupled plasma mass spectrometry) have also been demonstrated as capable of determining uranium in these materials at levels comparable to those which occur naturally. Sample preparation requirements and isotopic sensitivities vary widely among these techniques and should be considered carefully when choosing a method. This report discusses analytical techniques used for evaluating uranium in biological matrices (primarily urine) and limits of detection reported in the literature. No cost comparison is attempted, although references are cited which address cost. Techniques discussed include:

- $\alpha$-particle spectrometry,

- liquid scintillation spectrometry,

- fluorometry,

- phosphorometry,

- neutron activation analysis,

- fission-track counting,

- UV-visible absorption spectrophotometry,

- resonance ionization mass spectrometry, and

- inductively-coupled plasma mass spectrometry.
\end{abstract}

A summary table of reported limits of detection and of the more important experimental conditions associated with these reported limits is also provided. 
 


\section{ACRONYMS}

ASTM American Society for Testing and Materials

CV coefficient of variation

DNA delayed neutron analysis

EML

U. S. Department of Energy Environmental Measurements Laboratory

FWHM full peak width at half-maximum

FTA fission track analysis

ICP inductively coupled plasma

ICP-MS inductively coupled plasma mass spectrometry

KPA kinetic phosphorescence analysis

$L_{\mathrm{D}} \quad$ detection limit

MS mass spectrometry

NAA neutron activation analysis

ORNL Oak Ridge National Laboratory

PERALS photon-electron rejecting alpha liquid scintillation

RIMS resonance ionization mass spectrometry

RIS

resonance ionization spectroscopy

UV

ultraviolet 


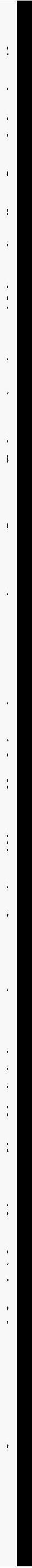




\section{Review of Uranium Bioassay Techniques}

\section{ANALYTICAL CHEMISTRY OF URANIUM}

Uranium in human excreta or tissues can be quantitatively determined at levels important for either occupational or environmental exposure monitoring by several radiometric, photometric, and mass spectrometric methods. Summary reports describing many of the methods applied to uranium analysis are available. ${ }^{14} \mathrm{~A}$ comprehensive review of performance and cost factors for a variety of nonradiometric techniques used to determine low levels of long-lived radionuclides, ${ }^{5}$ and a survey of reported limits of detection and cost of environmental samples by commercial laboratories, ${ }^{6}$ have also been published. Widely used analytical methods for uranium include $\alpha$-particle spectrometry and liquid scintillation spectrometry, which utilize the natural radioactivity of uranium, and photometric techniques such as fluorometry and phosphorometry. Less widely used, but extremely sensitive, neutron activation analysis and fission-track counting take advantage of the high thermal neutron absorption and fission cross sections of ${ }^{238} \mathrm{U}$ and ${ }^{235} \mathrm{U}$. The determination of uranium in urine by ultraviolet (UV)-visible radiation absorption spectrophotometry of a colored complex is also used at levels appropriate for preventing nephrotoxic effects. Both resonance ionization mass spectrometry and inductively-coupled plasma mass spectrometry are emerging techniques for isotopic uranium bioassay of low concentrations at reasonable cost.

Environmental levels of uranium in human excreta are highly variable, depending on uranium concentrations in air, food and water, and on the health of the individual. Publication 23 of the International Commission on Radiological Protection provides model values of $0.05-0.5 \mu \mathrm{g} / \mathrm{d}$ (corresponding to $0.04-0.4 \mu \mathrm{g} / \mathrm{L}$ ) for urinary uranium excretion, and 1.4 to $1.8 \mu \mathrm{g} / \mathrm{d}$ for elimination in feces. ${ }^{7}$ Analytical techniques used as part of a radiation protection program should provide limits of detection comparable to or below these levels in order to differentiate between environmental and occupational uranium exposures. Other applications will have unique requirements for acceptable limits of detection.

This report focuses on providing basic information about techniques in use for evaluating uranium in biological matrices (primarily urine), and nominal reported limits of detection. No cost comparison is attempted, although references are cited which provide information for evaluating performance factors and relative costs of achieving uranium detection limits appropriate to specific applications. 


\section{UV - VISIBLE SPECTROPHOTOMETRY}

Hexavalent uranium forms colored complexes with a number of organic chelating agents such as dibenzoylmethane (DBM), 1-(2-pyridylazo)-2-naphthol (PAN), 5-dimethylamino-2-(2-thiazoylazo) (TAM), arsenazo $\mathrm{III}^{*}$, and 8-hydroxyquinoline, as well as with organic and inorganic reagents containing oxygen and sulfur proton donors such as hydrogen peroxide, alcoholic ammonium thiocyanate, and ascorbic acid. ${ }^{8}$ Arsenazo III, a bisazo dye based on chromotrophic acid and o-aminophenylarsonic acid, is a member of a family of bisazo derivatives of chromotrophic acid which are among the most sensitive reagents for the spectrophotometric determination of uranium. ${ }^{9}$ Uranyl ion $\left(\mathrm{UO}_{2}\right)^{2+}$ in the presence of arsenazo III forms a colored complex with high molar absorptivity. ${ }^{10}$ An analytical procedure has been developed in which urinary uranium concentration is determined from the absorbance of uranyl-arsenazo III complex at $653 \mathrm{~nm} .{ }^{11}$ Uranium in $50-\mathrm{cm}^{3}$ or $100-\mathrm{cm}^{3}$ aliquots is oxidized by this procedure to U(VI) with nitric acid, and then separated directly from urine by anion exchange prior to complexing by the addition of arsenazo III. Chemical recovery in excess of $80 \%$ and detection of $5-66 \mu \mathrm{g} / \mathrm{L}^{238} \mathrm{U}$ added to urine are reported. Determination of $U(V I)$ in the presence of thorium (the only interferant which is not easily masked) has been demonstrated for uranium and thorium in the concentration range $100-700 \mu \mathrm{g} / \mathrm{L}$ using second-derivative spectroscopy, with coefficients of variation (CV) of $2.6 \%$ (uranium) and $1.5 \%$ (thorium) in a mixture containing $345 \mu \mathrm{g} / \mathrm{L}$ uranium and $351 \mu \mathrm{g} / \mathrm{L}$ thorium. ${ }^{12}$ Nakashima reports achieving a detection limit of $0.29 \mu \mathrm{g} / \mathrm{L}$ for $\mathrm{U}(\mathrm{VI})$ in $100 \mathrm{~mL}$ of seawater, using a very simple procedure in which uranium-arsenazo III complex adsorbed on anion exchange resin was determined directly in a flow cell by the difference in absorbance at $665 \mathrm{~nm}$ and $800 \mathrm{~nm}$ using a dual-beam spectrophotometer. ${ }^{13}$

\section{FLUOROMETRY AND PHOSPHOROMETRY**}

Fluorometric uranium analysis is based on excitation of the uranyl ion by ultraviolet radiation absorption, followed by spontaneous photon emission and decay to the ground electronic state. The photon emission rate is proportional to the number of excited uranyl ions, whose mean lifetime is on the order of a few hundred microseconds in the absence of secondary reactions (quenching). Emitted photons have a lower energy than absorbed photons because of radiationless energy losses within the excited uranyl ion. The term

\footnotetext{
*Arsenazo III: (1,8-dihydroxynaphthalene-3,6-disulphonic acid-bis(azophenyl arsenic acid))

**The terms fluorimetry and phosphorimetry are occasionally used for fluorometry and phosphorometry, respectively.
} 
"fluorometry" is used when the emitted light intensity is measured while excitation is still occurring; "phosphorometry," when the emission intensity is measured a few microseconds after excitation of the uranyl ion by a pulsed light source.

Fluorometric methods for uranium are commonly variations on classical methods, wherein small (usually aqueous) samples are added to solid $\mathrm{NaF}$, or to a $\mathrm{NaF} / \mathrm{LiF}$ flux, which is then fused by heating. ${ }^{14,15}$ Fusion incorporates the uranium uniformly in the melt and eliminates water, organics, and volatile inorganics. A fluorometer is used to irradiate the cooled sample with UV light in the 320 to $370 \mathrm{~nm}$ range, and fluorescence intensity at 530 to $570 \mathrm{~nm}$ is measured at $45^{\circ}$ to $90^{\circ}$ to the incident beam. An empirical equation describing analytical precision of the fluorometric method as a function of uranium concentration in water is provided by an American Society for Testing and Materials procedure:

$$
\sigma=0.0024+0.2001[\mathrm{U}]^{1.5293}
$$

where $\sigma$ is the standard deviation about the mean uranium concentration $[\mathrm{U}]$ in $\mathrm{mg} / \mathrm{L} .{ }^{16}$ The CV determined from this relationship is illustrated graphically in Fig. 1. A CV of $10 \%$ is expected for a $0.1-\mathrm{mL}$ sample at a concentration of about $30 \mu \mathrm{g} / \mathrm{L}$ (total sample mass, about $3 \mathrm{ng}$ ) by the ASTM expression. This precision would be expected for the same mass in $1 \mathrm{~L}$ of urine if all the uranium could be concentrated and recovered for fluorometry. Uranium in a $0.1-\mathrm{mL}$ urine sample in concentrations from 1 to $1,000 \mu \mathrm{g} / \mathrm{L}$ can be measured fluorometrically without pretreating the urine, except for drying. ${ }^{17-19}$ Quenching effects are not significant because of the small analyte volume, but background fluorescence reduces accuracy in the concentration range 1 to $10 \mu \mathrm{g} / \mathrm{L}$. Detection of $0.1 \pm 0.1 \mu \mathrm{g}$ uranium $/ \mathrm{L}$ after ion-exchange separation from $10 \mathrm{~mL}$ of urine has been reported. ${ }^{20}$

The use of UV lasers provides precise frequency control for reduced interference, and increased incident light intensity for stronger induced fluorescence. Detection of $1.0 \mu \mathrm{g}$ uranium $/ \mathrm{L}$ in the equivalent of $0.2 \mathrm{~mL}$ of urine has been reported using $337-\mathrm{nm}$ laser light pulsed at $16 \mathrm{~Hz}$; phosphorescence with decay times of about $100 \mu \mathrm{s}$ was measured in this study at $516 \mathrm{~nm}$ after organic fluorescence with 4- to 10-ns lifetimes had decayed. ${ }^{21}$ Detection of $10^{-5} \mu \mathrm{g} / \mathrm{L}$ uranium was reported by coprecipitating the uranium from aqueous solution with $\mathrm{CaF}_{2}$, and then measuring laser-induced phosphorescence in the fused precipitate; the luminescence intensity was reported to be linear from 0.002 to $0.02 \mu \mathrm{g}$ uranium $/ \mathrm{L}^{22}$ The use of pulsed dye-laser excitation of the uranyl ion, corrected for matrix quenching and temperature effects, provides very precise measurement of uranium in synthetic urine at $7 \mu \mathrm{g} / \mathrm{L}$ when samples are wet-ashed in nitric and perchloric acids and then taken up in phosphoric acid for analysis. ${ }^{23}$

Kinetic phosphorescence analysis (KPA) estimates uranyl ion concentration by observing phosphorescence intensity with time after pulsed laser excitation. ${ }^{1,24}$ Decay of the resulting $\mathrm{UO}_{2}^{2+}$ excited state follows first-order kinetics, so that 


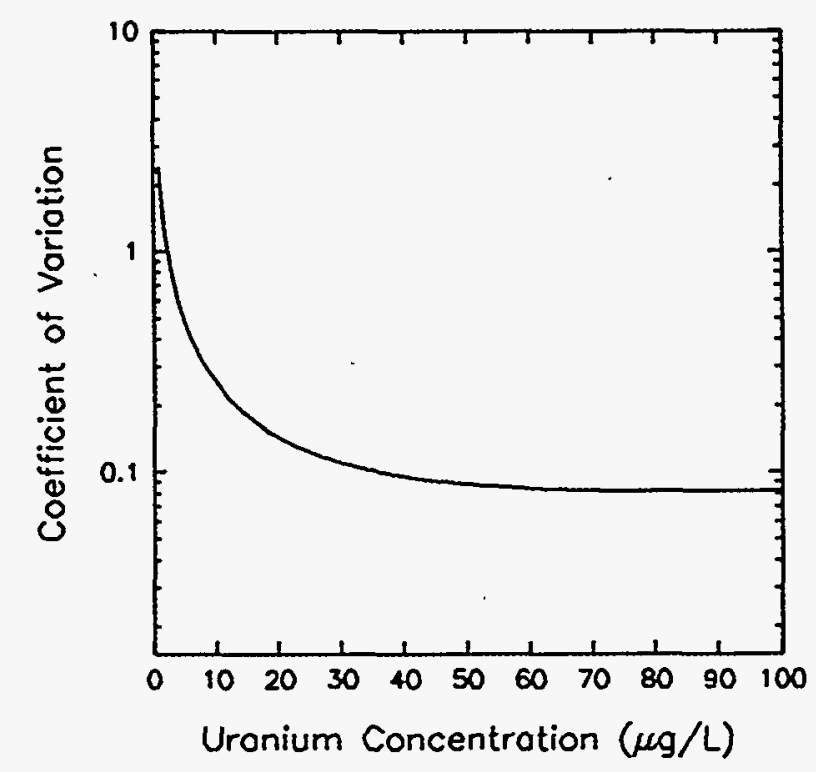

Fig. 1. Coefficient of variation for fluorometric determination of uranium in water by ASTM D 2907-75.

$$
\ln I_{t}=\ln I_{0}-\left(k_{\mathrm{p}}+k_{\mathrm{q}}\right) t
$$

where $I_{t}$ and $I_{0}$ are phosphorescence intensities at times $t$ and 0 , respectively, and $k_{\mathrm{p}}$ and $k_{\mathrm{q}}$ are rate constants for phosphorescence and nonradiative (quenched) decay processes. The initial phosphorescence intensity $I_{0}$ is determined from the intercept of the plot of $\ln I_{t}$ vs $t$, and is related to uranyl ion concentration by calibrations using standard solutions. The KPA limit of detection for $\mathrm{U}_{3} \mathrm{O}_{8}$ dissolved in nitric acid and complexed with a phosphate solution is reported to be about $1 \mathrm{ng} / \mathrm{L}$, with a $4 \%-7 \% \mathrm{CV}(1 \%-3 \%$ at higher concentrations).* Linear response from $1 \mathrm{ng} / \mathrm{L}$ to $5 \mathrm{mg} / \mathrm{L}$ is possible if detector saturation is accounted for during early decay times of more concentrated solutions. An ASTM test method using pulsed-laser phosphorimetric analysis for uranium above $50 \mathrm{ng} / \mathrm{L}$ in water is available. ${ }^{25}$ The KPA method has been used to measure background levels of uranium in urine in the $15-30 \mathrm{ng} / \mathrm{L}$ range with a $10 \mathrm{ng} / \mathrm{L}$ limit of detection. ${ }^{26}$ Development of a protocol for analyzing uranium in urine using KPA has been described, in which results (see Table 1) of

*The authors used a nitrogen-pumped dye laser at $420 \mathrm{~nm}$ with $0.1-0.5 \mathrm{~mW}$ of power, emitting pulses of 3-ns duration. Each analysis consisted of interrogating the sample at a $20-\mathrm{Hz}$ repetition rate for $50 \mathrm{~s}$. 
Table 1. Reported EML interlaboratory comparison results (ng/mL total uranium in urine)

\begin{tabular}{cccccc}
\hline $\begin{array}{c}\text { Added by } \\
\text { EML }\end{array}$ & RESL $^{*}$ & EML $^{\mathrm{b}}$ & Lab 2 $^{\circ}$ & Lab 3 $^{\mathrm{d}}$ & Lab $^{\mathrm{c}}$ \\
\hline 0 & $0.12 \pm 0.02$ & $0.14 \pm 0.11$ & $0.04 \pm 0.04$ & $1 \pm 1$ & 8 \\
0 & $0.09 \pm 0.02$ & $-0.01 \pm 0.16$ & $0.03 \pm 0.03$ & $0 \pm 0$ & $<5$ \\
3.3 & $3.3 \pm 0.2$ & $3.3 \pm 0.3$ & $2.8 \pm 0.5$ & $3 \pm 1$ & $<5$ \\
6.1 & $5.8 \pm 0.3$ & $5.7 \pm 0.4$ & $5.9 \pm 0.9$ & $7 \pm 0$ & 8 \\
11.1 & $10.4 \pm 0.5$ & $11.3 \pm 0.5$ & $9.3 \pm 1.4$ & $13 \pm 2$ & 14 \\
17.6 & $16.5 \pm 0.8$ & $16.8 \pm 0.6$ & $15.6 \pm 2.4$ & $21 \pm 3$ & 14 \\
\hline
\end{tabular}

'U. S. Department of Energy Radiological and Environmental Sciences Laboratory; KPA method.

b. S. Department of Energy Environmental Measurements Laboratory; chemical separation followed by $\alpha$-particle energy spectrometry (5600-min count).

${ }^{\circ} \mathrm{Chemical}$ separation followed by fused-pellet fluorometry.

${ }^{d}$ Fused-pellet fluorometry.

'UV-visible spectrophotometry after separation by anion exchange and complexing with Arsenazo III.

an interlaboratory comparison* conducted by the U.S. Department of Energy Environmental Measurements Laboratory indicate that the method compares favorably with analysis by $\alpha$-particle spectrometry (5600-min counting time), fused-pellet fluorometry, and UV-visible spectrophotometry. ${ }^{27}$

\section{METHODS BASED ON MEASURING ALPHA RADIOACTIVITY}

Both $\alpha$-particle energy spectrometry and gross $\alpha$-decay counting take advantage of the natural radioactivity of uranium to determine uranium quantitatively in human excreta and tissues. Isotopic identification, important for internal dosimetry, is possible using $\alpha$-particle spectrometry. Techniques using solid-state (surface-barrier and passivated ion-implanted) silicon detectors and liquid scintillation are available for $\alpha$-particle spectrometric uranium bioassay.

*Natural urine with known amounts of uranium added by the testing laboratory was used for the intercomparison study. 
Silicon semiconductor surface-barrier and ion-implanted detectors are widely used for $\alpha$-particle spectrometry because of the $20-40 \mathrm{keV}$ full peak width at half-maximum (FWHM) energy resolution, which is similar in magnitude to differences in $\alpha$-particle energies associated with the different uranium isotopes. This technique requires radiochemical separation of the uranium from the biological matrix followed by electrodeposition, evaporation, or coprecipitation with $\mathrm{LaF}_{3}$ or $\mathrm{NdF}_{3}$ in a thin, almost massless, configuration on a substrate that can be inserted into the counting chamber. ${ }^{22-31}$ The concentration of uranium in urine, feces, or tissue which can be determined with a given precision depends on factors which include the detector efficiency, chemical recovery, background, sample size, and counting time. Estimates of uranium detection limits $L_{D}$ in terms of concentration in the analyte can be derived ${ }^{2}$ for $\alpha$-particle spectrometry using silicon surface-barrier detectors by assuming that 10 net counts is significantly greater than zero, with $\mathrm{CV}=30 \%$ $(\sigma \propto \sqrt{ } 10 \propto 3)$, and by substituting the typical bioassay parameters into the expression shown as Equation 3:

Counting time, $t=24 \mathrm{~h}=86,400 \mathrm{~s}$

Counting efficiency, $\epsilon=0.3$

Sample volume, $V=1 \mathrm{~L}$

Chemical recovery $\approx 100 \%$.

$$
\mathrm{L}_{\mathrm{D}}\left(\frac{\mu \mathrm{g}}{\mathrm{L}}\right) \approx \frac{10 \text { counts }}{t \in k V S}=\frac{10 \text { counts }}{(86,400 \mathrm{~s})(0.30)(1 \mathrm{~L}) k S}=\frac{3.86 \times 10^{-4}}{k S}
$$

where $k=$ the $\alpha$-particle yield per disintegration, and $S=$ specific activity $(\mathrm{Bq} / \mu \mathrm{g})$.

Table 2 shows nuclear data relevant to $\alpha$-particle spectrometry for uranium, and provides estimates of concentration detection limits for uranium isotopes from the nuclear data and the expression given in Equation 3. Detection limits are lower if counts are summed under all the $\alpha$-particle energies $(k=1)$ for a particular isotope, which is a common practice, especially in cases where the $\alpha$-energy separation is too small for resolution by the detector.

Liquid scintillation spectroscopy is attractive for quantitative determination of $\alpha$-particle emitters because of its $4 \pi$ geometry, high counting efficiency (near $100 \%$, since sample self-absorption is not a factor), and because sample preparation can be relatively straightforward. Fairly recent developments have resulted in liquid scintillation counting equipment designed for $\alpha$-, rather than $\beta$-particle, emissions, and techniques which partially overcome disadvantages of high background (resulting from sensitivity to accompanying $\beta$ and $\gamma$ radiation) and sensitivity of scintillator performance to water, acids, or salts which may be introduced along with the analyte. Design of a Photon-Electron Rejecting Alpha Liquid Scintillation (PERALS) spectrometer, which uses pulse-shape discrimination for rejecting $\beta$-particle and $\gamma$-ray signals, thereby significantly reducing background, and a method for separating and counting uranium and thorium in phosphate-containing materials (including 
Table 2. Uranium concentration detection limits for $\alpha$-particle spectrometry using silicon detectors

\begin{tabular}{ccccc}
\hline Isotope & $\begin{array}{c}\alpha \text {-Particle } \\
\text { energy } \\
(\mathrm{MeV})\end{array}$ & $\begin{array}{c}\alpha \text {-Particle } \\
\text { yield per } \\
\text { disintegration } \\
(\mathrm{k} \text {, dimensionless })\end{array}$ & $\begin{array}{c}\text { Specific } \\
\text { activity } \\
(\mathrm{Bg} / \mu \mathrm{g})\end{array}$ & $\begin{array}{c}\text { Approximate } \\
\text { detection } \\
\text { limit } \\
(\mu \mathrm{g} / \mathrm{L})\end{array}$ \\
\hline${ }^{232 \mathrm{U}}$ & 5.32 & 0.69 & $7.92 \times 10^{5}$ & $7 \times 10^{-10}$ \\
${ }^{233} \mathrm{U}$ & 4.82 & 0.84 & $3.57 \times 10^{2}$ & $1 \times 10^{-6}$ \\
${ }^{234} \mathrm{U}$ & 4.77 & 0.72 & $2.32 \times 10^{2}$ & $2 \times 10^{-6}$ \\
${ }^{235} \mathrm{U}$ & 4.40 & 0.57 & $7.98 \times 10^{-2}$ & $8 \times 10^{-3}$ \\
${ }^{238} \mathrm{U}$ & 4.19 & 0.77 & $1.24 \times 10^{-2}$ & $4 \times 10^{-2}$ \\
\hline
\end{tabular}

animal wastes) have been described. ${ }^{3}$ Light intensity in a liquid scintillator from an $\alpha$-particle is linear with the particle's energy in the 4- to $7-\mathrm{MeV}$ range, which includes the 4- to $5-\mathrm{MeV}$ range for most uranium $\alpha$ energies. The precision of the method is reflected by the scintillation peak width at half-maximum, about $200 \mathrm{keV}$ at an $\alpha$-particle energy of $4 \mathrm{MeV}$, rising to $300 \mathrm{keV}$ at $6 \mathrm{MeV}$. Liquid-liquid extraction techniques using an organic phasesoluble complex of the analyte, with an organic scintillator having no aqueous phaseaccepting components but containing a solvent extraction or phase transfer agent, produces the best energy resolution by reducing interferants introduced with the analyte into the scintillator medium. Energy resolution is also enhanced by the choice of an optimal sample size, efficient light collection and reflection to the phototube, and a minimal number of refractive index interfaces in the light collection system. Electronic pulse-shape discrimination in PERALS provides a means of rejecting responses to interfering $\beta$ and $\gamma$ radiations so that background count levels approach those typical for surface-barrier detectors. Use of the techniques described above can result in energy resolution of about $250 \mathrm{keV}$ FWHM for a $5-\mathrm{MeV} \alpha$ particle, and a detection limit of $0.01 \mathrm{cpm}$ or lower, giving detection limits comparable to those in Table 2.

\section{NEUTRON IRRADIATION METHODS}

Two types of nuclear reactions provide sensitive methods for determining uranium in biological tissue or excreta. Neutron activation analysis (NAA) takes advantage of the transmutation of ${ }^{238} \mathrm{U}$ to short-lived ${ }^{239} \mathrm{~Np}$, and both fission-track analysis (FTA) and delayed neutron analysis (DNA) can be used to determine ${ }^{235} U$ with its large thermal neutron fission cross section. Most applications of neutron irradiation methods for measuring uranium in 
biological samples use high thermal neutron fluence rates available in nuclear reactors or particle accelerators. Typical neutron fluence rates used for the limits of detection cited in this section are on the order of $10^{13} \mathrm{~cm}^{-2} \mathrm{~s}^{-1}$.

In neutron activation analysis, ${ }^{238} \mathrm{U}$ absorbs thermal neutrons in an $n-\gamma$ reaction to form ${ }^{239} \mathrm{U}$, which decays rapidly $\left(\mathrm{T}_{12}=23.5 \mathrm{~min}\right)$ by $\beta$-decay to ${ }^{239} \mathrm{~Np}$. The ${ }^{239} \mathrm{~Np}$ is itself a shortlived species $\left(\mathrm{T}_{1 / 2}=2.34 \mathrm{~d}\right)$ which decays by emission of a $\beta$ particle to ${ }^{239} \mathrm{Pu}$. Photons associated with the decay of either ${ }^{239} \mathrm{U}$ or ${ }^{239} \mathrm{~Np}$ can be used to estimate the original amount of ${ }^{238} \mathrm{U}$ present in the sample. The detection limit of the method depends on the thermal neutron fluence rate at which the sample is exposed and the time of exposure, since the maximum induced activities of both ${ }^{239} \mathrm{U}$ and its daughter, ${ }^{239} \mathrm{~Np}$, are governed by

$$
A(t)=\lambda N(t)=\varphi \sigma_{c} n\left(1-\mathrm{e}^{-\lambda t}\right)
$$

where

$$
\begin{aligned}
& A(t)=\text { activity of }{ }^{239} \mathrm{U} \text { at time } t \\
& \lambda=4.92 \times 10^{-4} \mathrm{~s}^{-1} \text {, the radioactive decay constant for }{ }^{239} \mathrm{U}, \\
& N(t)=\text { the number of }{ }^{239} \mathrm{U} \text { atoms present at time } t \\
& \varphi=\text { neutron fluence rate }\left(\mathrm{cm}^{-2} \mathrm{~s}^{-1}\right) \\
& \sigma_{\mathrm{c}}=2.73 \times 10^{-24} \mathrm{~cm}^{2}, \text { the } \\
& n=\text { the number of }{ }^{238} \mathrm{U} \text { atoms in the sample. }
\end{aligned}
$$

Natural uranium in high-purity silicon has been determined by NAA down to levels of $10^{-5} \mu \mathrm{g}$, but interferences from other activated species in biological excreta make pre- or post-irradiation separation of the activation products a requirement for obtaining useful detection limits for radiobioassay. The separation process introduces the possibility of contaminating the sample if performed prior to irradiation, and increases the handling and related personnel exposure for highly radioactive samples if performed after neutron activation takes place. Limits of detection for urinary ${ }^{238} \mathrm{U}$ have been reported as low as $1 \times 10^{-3} \mu \mathrm{g} / \mathrm{L}$ by measuring the induced ${ }^{239} \mathrm{U}$ activity after solvent extraction. ${ }^{32}$ Others report measuring uranium concentrations of $5 \mu \mathrm{g} / \mathrm{L}$, both from induced ${ }^{239} \mathrm{~Np}$ activity in $1-\mathrm{mL}$ urine samples which were irradiated and then separated on anion exchange resins, ${ }^{33}$ and in urinary uranium which was complexed with oxime and absorbed on activated carbon prior to neutron irradiation and determination of the resulting ${ }^{239} \mathrm{U}$ activity. ${ }^{34}$ Determination of $10^{-5} \mu \mathrm{g}^{230} \mathrm{Th}$, a long-lived $\alpha$-emitting daughter in the ${ }^{238} \mathrm{U}$ decay chain that transmutes to short-lived ${ }^{231}$ Th in an $n-\gamma$ reaction, has also been reported, and might be useful for estimating natural uranium in excreta. ${ }^{35}$

Delayed neutron analysis (DNA) is a sensitive method for determining ${ }^{235} \mathrm{U}$ because the fissioning of the uranium nucleus creates radioactive nuclei, in about $1.6 \%$ of the fission events, which decay by $\beta^{-}$particle emission to unstable daughters that further decay by 
spontaneous neutron emission. Measuring the delayed neutron emission rate provides a quantitative estimate of the ${ }^{235} \mathrm{U}$ present in the sample. The $\beta^{-}$-emitting fission products decay with half-times ranging from 2 to $55 \mathrm{~s}$, so that their activity in a thermal neutron field approsches its maximum value quickly. Levels on the order of $10^{-4} \mu \mathrm{g}^{235} \mathrm{U}\left(0.014 \mu \mathrm{g} \mathrm{U}_{\mathrm{nxx}}\right)$ can be detected, and $10^{-3} \mu \mathrm{g}$ measured quantitatively, in samples with no interferences after exposure times of about 1 min in a neutron fluence rate of $\varphi \sim 3 \times 10^{13} \mathrm{~cm}^{-2} \mathrm{~s}^{-1}$ (refs. 36-38). Detection of $1.5 \mathrm{pCi}{ }^{235} \mathrm{U} / \mathrm{L}(0.0069 \mu \mathrm{g} / \mathrm{L}), 1 \mu \mathrm{g} \mathrm{U}_{\mathrm{na}} / \mathrm{L}$, and $4 \mu \mathrm{g}$ depleted uranium/L $\left(0.18 \%{ }^{235} \mathrm{U}\right)$ has been reported using $25 \mathrm{~mL}$ of urine irradiated and analyzed for delayed neutron emissions without any sample processing. ${ }^{39}$ Uranium in $100-\mathrm{mL}$ aliquots of urine complexed with thiocyanate and adsorbed on anion exchange resin prior to irradiation has been measured at concentrations of approximately $0.5 \mu \mathrm{g} / \mathrm{L}$.

Fission track analysis (FTA) is available as a sensitive analytical method in which fission fragments from ${ }^{235} \mathrm{U}$ exposed to thermal neutrons produce tracks in materials such as polycarbonate films (Lexan), mica, and fused silica. These tracks are then developed to a size visible under the microscope, and the amount of ${ }^{235} \mathrm{U}$ present in the sample can be estimated from the track density. The method is extremely sensitive; detection limits in the range 0.1 to $0.7 \mu \mathrm{g} / \mathrm{L}$ have been observed, and a limit of $0.01 \mu \mathrm{g} / \mathrm{L}$ is believed possible, using $0.05 \mathrm{~mL}$ urine on Lexan film exposed to a thermal neutron fluence of $\phi \sim 10^{17} \mathrm{~cm}^{-2}$ (ref. 2).

\section{MASS SPECTROMETRIC TECHNIQUES}

Mass spectrometry provides a powerful and sensitive analytical tool which is capable of determining both mass and isotopic composition of an analyte. Exploration of its usefulness in determining uranium in biological materials has increased greatly since the late 1970s. Mass spectrometric techniques tend to be described in terms of the means by which a sample is ionized prior to injection into the mass spectrometer. Two such techniques used for ionizing samples containing uranium are resonance ionization and inductively coupled plasma.

Resonance ionization spectroscopy (RIS) uses tuned laser radiation to selectively raise uranium atoms in the gas phase to one or more intermediate quantum energy states before photoionization and detection. ${ }^{41-43}$ Intermediate excited states can be chosen which are specific for the atom of interest so that isotopic resolution is possible. The charge produced by the free electrons can be measured, or the ions can be analyzed by mass spectrometry. Gaseous neutral atoms are generated from a solid substrate by thermally heating the sample or by bombarding the sample surface with ion beams (sputtering). Pulsed lasers are normally used both to excite and to photoionize the uranium. The resonance ionization mass spectrometry (RIMS) technique has been described by several authors. ${ }^{4-48}$ A RMMS methodology for analyzing urinary uranium has been described, in which 10-mL aliquots of artificial urine spiked with uranyl nitrate are passed through anion exchange columns, and 
the eluate is dried on a silicon disk prior to analysis. The dried sample is vaporized by sputtering with an Ar ion beam. A detection limit of $1 \mu \mathrm{g}$ uranium $/ \mathrm{L}$ is reported, and the authors believe the detection limit can easily be reduced to $0.05 \mu \mathrm{g} / \mathrm{L}$ by better control of reagent purity. Determination of the ${ }^{238} \mathrm{U}{ }^{235} \mathrm{U}$ ratio in the range 0.3 to 10 is also reported to within $20 \%$ of the known value. The authors also present favorable cost estimates for routinely determining uranium in urine at different analyte concentrations and limits of detection using the technique. ${ }^{49}$

Inductively coupled plasma-mass spectrometry (ICP-MS) uses an inductively-coupled plasma as an ion source for a mass spectrometer. A sample introduction device introduces samples into the plasma, as either a dry vapor or a fine mist. Options for introducing liquid samples include pneumatic nebulization, electrothermal vaporization, flow injection, and direct injection. Laser ablation is a common method for introducing solid samples into the plasma. Argon is often used as the carrier gas. Radiofrequency fields at the tip of a quartz torch generate a high-temperature $(5000-8000 \mathrm{~K})$ plasma at atmospheric pressure in the carrier gas, which desolvates, atomizes, and ionizes the sample; a portion is then drawn into the evacuated mass spectrometer region through a series of small orifices. ICP-MS detection limits are generally competitive with those for methods which depend on natural radioactivity for radionuclides with half-lives exceeding about $10^{4}$ years. ${ }^{4}$ A comparison of ICP-MS and delayed neutron analysis shows that ICP-MS precision and accuracy compare favorably with DNA for measuring $0-372 \mathrm{ng} / \mathrm{L}{ }^{235} \mathrm{U}$ and $0-8 \mu \mathrm{g} / \mathrm{L}^{238} \mathrm{U}$ in urine. ${ }^{50 *}$ Results of the comparison are reproduced in Table 3 and graphically in Figs. 2 and 3. Human Lung Standard Reference Material from the National Institute of Standards and Technology with $8.1 \mathrm{ng}$ uranium per gram was analyzed by ICP-MS, using ${ }^{205} \mathrm{Tl}$ and ${ }^{209} \mathrm{Bi}$ as internal standards, with good results. ${ }^{51}$ Uranium was also measured at about $55 \mathrm{ng} / \mathrm{g}$ in human bone using an in-house standard material in this study. Results from both the lung and bone analyses are shown in Table 4.

\section{CONCLUSIONS}

This review illustrates that a variety of analytical techniques is available for evaluating uranium in excreta and tissues at levels appropriate for occupational exposure control and evaluation. A few (fluorometry, kinetic phosporescence analysis, $\alpha$-particle spectrometry, neutron irradiation techniques, and inductively-coupled plasma mass spectrometry) have also been demonstrated as capable of determining uranium in these materials at levels comparable to those which occur naturally. A summary of reported limits of detection and the more important experimental conditions associated with the reported analytical levels are shown in Table 5.

\footnotetext{
${ }^{*}$ Concentrations of ${ }^{238} \mathrm{U}$ were inferred from the ${ }^{235} \mathrm{U}$ DNA results using assumptions about isotopic ratios in the sample.
} 
Table 3. Comparison of analytical results for uranium in urine: ICP-Mass spectrometry and delayed neutron analysis

\begin{tabular}{|c|c|c|c|c|c|}
\hline \multicolumn{3}{|c|}{${ }^{235} \mathrm{U}$ concentration (ng L ${ }^{-1}$ ) } & \multicolumn{3}{|c|}{${ }^{228} \mathrm{U}$ concentration $\left(\mu \mathrm{g} \mathrm{L}^{-1}\right)$} \\
\hline $\begin{array}{l}\text { Added by } \\
\text { laboratory }\end{array}$ & $\begin{array}{l}\text { ICP-MS } \\
\text { result }^{2}\end{array}$ & $\begin{array}{l}\text { DNA } \\
\text { result }^{b}\end{array}$ & $\begin{array}{c}\text { Added by } \\
\text { lab }\end{array}$ & $\begin{array}{c}\text { ICP-MS } \\
\text { result }\end{array}$ & $\begin{array}{l}\text { DNA } \\
\text { result }^{b}\end{array}$ \\
\hline 0 & $<5$ & $<5$ & 0 & $0.02 \pm 0.01$ & $<1$ \\
\hline 74 & $97 \pm 20$ & $76 \pm 10$ & 2.0 & $2.10 \pm 0.10$ & $2.02 \pm 0.64$ \\
\hline 112 & $174 \pm 30$ & $112 \pm 12$ & 3.0 & $3.23 \pm 0.17$ & $3.32 \pm 0.65$ \\
\hline 149 & $197 \pm 35$ & $150 \pm 10$ & 4.0 & $5.25 \pm 0.21$ & $3.90 \pm 0.65$ \\
\hline 223 & $280 \pm 40$ & $236 \pm 12$ & 5.0 & $5.45 \pm 0.27$ & $5.12 \pm 0.37$ \\
\hline 298 & $322 \pm 40$ & $310 \pm 12$ & 6.0 & $6.45 \pm 0.32$ & $5.85 \pm 0.97$ \\
\hline 372 & $419 \pm 45$ & $387 \pm 16$ & 8.0 & $8.91 \pm 0.45$ & $8.29 \pm 0.56$ \\
\hline
\end{tabular}

Concentration \pm 1 standard deviation based on counting statistics for a single analysis.

$\mathrm{Mean}$ concentration \pm 1 standard deviation based on approximately 20 analyses. ${ }^{238} \mathrm{U}$ concentration is inferred from the ${ }^{233} \mathrm{U}$ DNA result using assumptions about isotopic ratios in the sample.

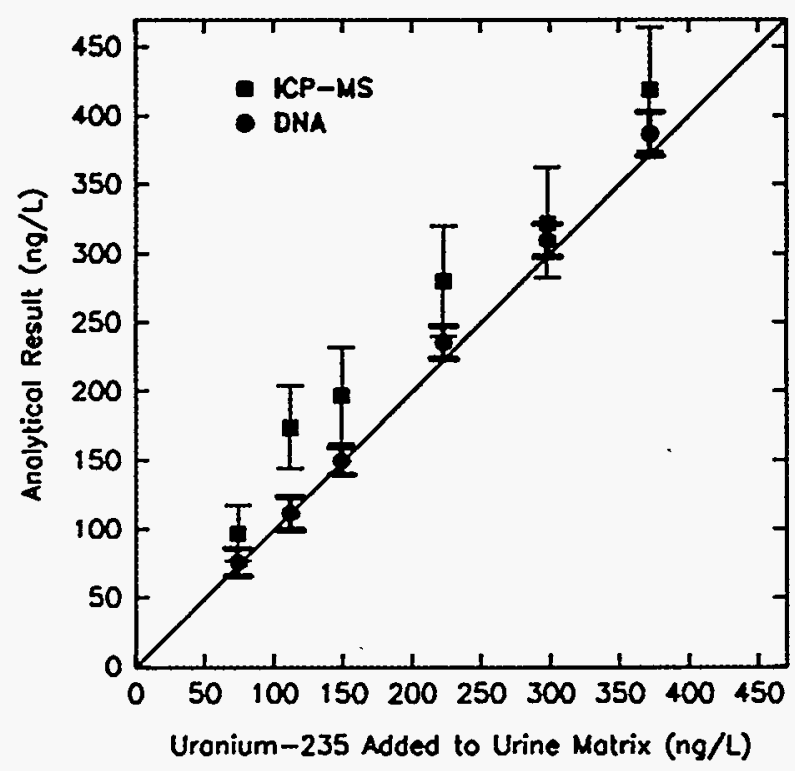

Fig. 2. Comparison of analytical results for ${ }^{235} \mathrm{U}$ in urine: ICP-Mass spectrometry and delayed neutron analysis. 


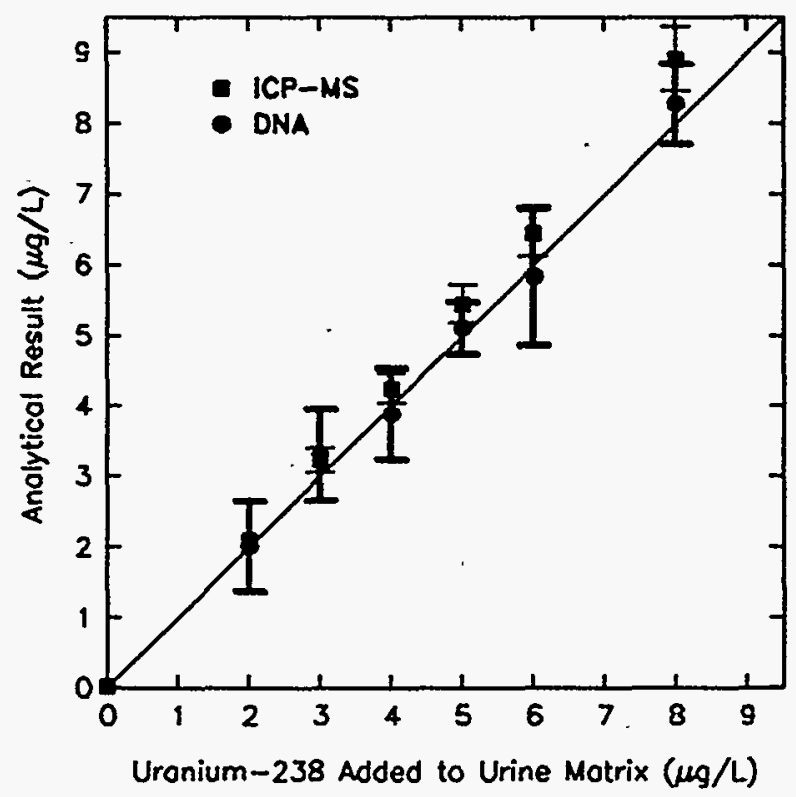

Fig. 3. Comparison of analytical results for ${ }^{238} \mathrm{U}$ (inferred from ${ }^{235} \mathrm{U}$ results) in urine: ICP-Mass spectrometry and delayed neutron analysis.

Table 4. ICP-MS analytical results for uranium in biological materials

\begin{tabular}{|c|c|c|c|c|c|}
\hline \multirow{2}{*}{$\begin{array}{l}\text { Biological } \\
\text { reference } \\
\text { material }\end{array}$} & \multirow{2}{*}{$\begin{array}{l}\text { Concentra- } \\
\text { tion of tissue } \\
\text { in solution } \\
(\mu \mathrm{g} / \mathrm{mL})\end{array}$} & \multirow[b]{2}{*}{$\begin{array}{l}\text { Measure- } \\
\text { ment no. }\end{array}$} & \multirow{2}{*}{$\begin{array}{c}\text { Reference } \\
\text { concentration } \\
(\mathrm{ng} / \mathrm{g})\end{array}$} & \multicolumn{2}{|c|}{$\begin{array}{l}\text { Measured concentration } \\
(\mathrm{ng} / \mathrm{g})\end{array}$} \\
\hline & & & & $\begin{array}{l}{ }^{205} \mathrm{Tl} \text { internal } \\
\text { standard }\end{array}$ & $\begin{array}{l}{ }^{200} \mathrm{Bi} \text { internal } \\
\text { standard }\end{array}$ \\
\hline \multirow[t]{3}{*}{ Human bone } & 400 & 1 & $a$ & $54.4 \pm 3.3$ & $55.6 \pm 3.3$ \\
\hline & & 2 & . & $58.1 \pm 3.4$ & $58.8 \pm 3.4$ \\
\hline & & 3 & & $62.1 \pm 3.5$ & $66.2 \pm 3.6$ \\
\hline \multirow[t]{3}{*}{ Human lung } & 400 & 1 & 8.1 & $7.37 \pm 0.27$ & $7.49 \pm 0.27$ \\
\hline & & 2 & & $8.01 \pm 0.28$ & $7.98 \pm 0.28$ \\
\hline & & 3 & & $8.03 \pm 0.28$ & $7.83 \pm 0.28$ \\
\hline
\end{tabular}

${ }^{a}$ The human bone was an in-house standard with no published uranium concentration reference value. 
Table 5. Reported uranium measurement levels in excreta and tissues for several analytical techniques

\begin{tabular}{|c|c|c|c|}
\hline Technique & \multicolumn{2}{|c|}{$\begin{array}{l}\text { Measurement level } \\
(\mathrm{n} g / \mathrm{L})\end{array}$} & Notes \\
\hline $\begin{array}{l}\text { UV-visible } \\
\text { spectropho- } \\
\text { tometry }\end{array}$ & \multicolumn{2}{|c|}{$5,000-66,000$} & $\begin{array}{l}\text { Anion exchange followed by formation of a colored } \\
\text { complex using Arsenazo III }\end{array}$ \\
\hline \multicolumn{4}{|l|}{$\begin{array}{l}\text { Fluorometry and } \\
\text { phosphorometry }\end{array}$} \\
\hline \multirow[t]{2}{*}{ Fluorometer } & \multirow{2}{*}{\multicolumn{2}{|c|}{$100 \pm 100$}} & $\begin{array}{l}\text { Standard deviation for determination of } U \text { in water } \\
\text { is given by the ASTM expression: }\end{array}$ \\
\hline & & & $\sigma=0.0024+0.2001[U]^{1.5293}$ \\
\hline UV Laser & \multicolumn{2}{|c|}{$1,000-7,000$} & $\begin{array}{l}\text { Detection of } 0.01 \mathrm{ng} / \mathrm{L} \mathrm{U} \text { in aqueous solution fol- } \\
\text { lowing } \mathrm{CaF}_{2} \text { precipitation and measurement of } \\
\text { phosphorescence in the fused precipitate has been } \\
\text { reported. }\end{array}$ \\
\hline $\mathrm{KPA}$ & \multicolumn{2}{|l|}{$15-30$} & Estimated detection limit, $\mathrm{L}_{\mathbb{D}} \sim 10 \mathrm{ng} / \mathrm{L}$. \\
\hline \multicolumn{4}{|l|}{$\begin{array}{l}\text { Natural radioactiv- } \\
\text { ity }\end{array}$} \\
\hline PERALS & & & $\begin{array}{l}\text { No direct measurements of uranium in biological } \\
\text { materials reported, but attainable levels are esti- } \\
\text { mated to be comparable to values reported below } \\
\text { for } \alpha \text {-spectrometry }\end{array}$ \\
\hline $\begin{array}{l}\alpha \text {-Spectrom- } \\
\text { etry }\end{array}$ & $\begin{array}{c}40 \\
8 \\
0.002\end{array}$ & $\begin{array}{l}\left({ }^{238} \mathrm{U}\right) \\
\left({ }^{235} \mathrm{U}\right) \\
\left({ }^{234} \mathrm{U}\right)\end{array}$ & $\begin{array}{l}\text { Approximate, based on } 24-\mathrm{h} \text { counting time, } 30 \% \\
\mathrm{CV} \text {, and other assumptions considered to be typical } \\
\text { of conditions for this type of analysis. }\end{array}$ \\
\hline \multicolumn{4}{|l|}{ Neutron irradiation } \\
\hline NAA & $0.001-5,000$ & $\left({ }^{238} U\right)$ & $\varphi_{\mathrm{z}} \sim 3 \times 10^{13} \mathrm{~cm}^{-2} \mathrm{~s}^{-1}$ \\
\hline DNA & 7 & $\left({ }^{235} \mathrm{U}\right)$ & $\varphi_{\mathrm{n}} \sim 3 \times 10^{13} \mathrm{~cm}^{-2} \mathrm{~s}^{-1}, 25 \mathrm{~mL}$ urine \\
\hline FTA & $0.1-0.7$ & $\left.{ }^{235} \mathrm{U}\right)$ & $\Phi_{\mathrm{n}} \sim 3 \times 10^{17} \mathrm{~cm}^{-2}, 0.05 \mathrm{~mL}$ urine \\
\hline \multicolumn{4}{|l|}{$\begin{array}{l}\text { Mass spectro- } \\
\text { metry }\end{array}$} \\
\hline RIS & 1,000 & & $\begin{array}{l}\text { Capable of isotopic analysis ( } \pm 20 \% \text { uncertainty). } \\
\text { An attainable detection level of about } 50 \mathrm{ng} / \mathrm{L} \text { is } \\
\text { suggested. }\end{array}$ \\
\hline ICP-MS & $\begin{array}{c}2,000-8,000 \\
74-372\end{array}$ & $\begin{array}{l}\left({ }^{238} U\right) \\
\left({ }^{235} U\right)\end{array}$ & $\begin{array}{l}\text { Generally competitive with } \alpha \text {-spectrometric } \\
\text { methods for radionuclides with } T_{1 / 2}>10^{4} \mathrm{y} \text {. }\end{array}$ \\
\hline
\end{tabular}


Sample preparation requirements and isotopic sensitivities vary widely among analytical techniques and should be considered carefully when choosing a method. Sample preparation, which is not addressed here, often affects both the cost and limit of detection of a particular analytical method. Recent developments in ion-exchange materials and techniques have greatly simplified steps for concentrating uranium, and have enabled significant improvements in the limits of detection in some cases. Demonstrated performance using uranium in the matrix of interest to determine a suitable technique is preferable to reporting results for uranium in water or other matrices. Urine and feces, which are matrices of particular interest in radiation protection programs, are very complex and may require more careful sample preparation than that needed for relatively more simple media, such as tap water.

No analysis of cost or other programmatic factors important in choosing an analytical technique, besides reported analytical levels or detection limits, has been attempted in this report. Some techniques, particularly those involving neutron irradiation, are much less accessible at this time because of the lack of availability of nuclear reactors which provide the required thermal neutron fluence rates. Other neutron sources, such as accelerators, may be applicable for some types of analyses, however. 


\section{REFERENCES}

1. R. Brina and A. G. Miller, "Determination of Uranium and Lanthanides in Real-World Samples by Kinetic Phosphorescence Analysis," Spectroscopy 8 (1993).

2. F. F. Dyer et al., Evaluation of Isotope Dilution Mass Spectrometry for Bioassay Measurement of Uranium, Plutonium, and Thorium in Urine, ORNL/TM-9006, Martin Marietta Energy Systems, Inc., Oak Ridge Natl. Lab, 1984.

3. W. J. McDowell, Alpha Counting and Spectrometry Using Liquid Scintillation Methods, NAS-NS-3116, DE86007601, U.S. DOE, Office of Scientific and Technical Information, 1986.

4. R. R. Ross, J. R. Noyce, and M. M. Lardy, "Inductively Coupled Plasma-Mass Spectrometry: An Emerging Method for Analysis of Long-Lived Radionuclides," Radioactivity \& Radiochemistry 4, 24 (1993).

5. A W. McMahon, A Critical Intercomparison of Techniques for the Determination of Low Levels of Long Lived Radionuclides, AERE R 13617, Harwell Laboratory, Oxfordshire, England, 1989.

6. F. M. Cox and C. F. Guenther, "An Industry Survey of Current Lower Limits of Detection for Various Radionuclides," Health Physics 69, 121 (1995).

7. W. S. Snyder and M. J. Cook, Report of Task Group on Reference Man, Publication 23, International Commission on Radiological Protection, Oxford, 1975.

8. K. K. Gupta et al., "Spectrophotometric Determination of Uranium Using Ascorbic Acid as a Chromogenic Reagent," Talanta 40, 507 (1993).

9. T. M. Bhatti et al., "Spectrophotometric Determination of Uranium(VI) in Bacterial Leach Liquors Using Arsenazo-III," J. Chem. Tech. Biotechnol. 52, 331 (1991).

10. S. B. Savvin, "Analytical Use of Arsenazo III: Determination of Thorium, Zirconium, Uranium, and Rare Earth Elements," Talanta 8, 673 (1961).

11. I. K. Kressin, "Spectrophotometric Method for the Determination of Uranium in Urine," Anal. Chem. 56, 2269 (1984).

12. R. Kuroda et al., "Simultaneous Determination of Uranium and Thorium with Arsenazo III by Second-Derivative Spectrophotometry," Talanta 37, 619 (1990). 
13. T. Nakashima, K. Yoshimura, and T. Taketatsu, "Determination of Uranium (VI) in Seawater by Ion-Exchanger Phase Absorptiometry with Arsenazo III," Talanta 39, 523 (1992).

14. G. R. Price, R. J. Feretti, and S. Schwartz, "Fluorophotometric Determination of Uranium," Anal. Chem. 25, 322 (1953).

15. F. A. Centanni, A. M. Ross, and M. A. DeSesa, "Fluorometric Determination of Uranium," Anal. Chem. 28, 1651 (1956).

16. American Society for Testing and Materials, "Microquantities of Uranium in Water by Fluorometry, ASTM Designation D 2907-75," Annual Book of ASTM Standards 11.02 Water (II), 458 (1983).

17. C. E. Gray, ed., Manual of Analytical Methods for the Environmental Health Laboratory, SAND-75-0014, Sandia Laboratories, Albuquerque, NM, 1975.

18. R. C. Baselt, Biological Monitoring Methods for Industrial Chemicals, Biomedical Publications, Davis, CA, 1980, p. 273.

19. H. L. Volchok and G. dePlanque, ed., "Fluorometric Determination of Uranium in Urine," EML Procedures Manual, HASL-300-EAD25, U. S. DOE, 1982.

20. I. A. Dupzyk and R. J. Dupzyk, "Separation of Uranium from Urine for Measurement by Fluorometry or Isotope Dilution Mass Spectrometry," Health Phys. 36, 526 (1979).

21. E. R. Hinton, Jr., Analysis of Uranium in Urine by Laser-Induced Fluorescence, Y/DK-266, Oak Ridge Y-12 Plant, Oak Ridge, TN, 1981.

22. D. L. Perry et al., "Detection of Ultratrace Levels of Uranium in Aqueous Samples by Laser-Induced Fluorescence Spectrometry," Anal. Chem. 53, 1048 (1981).

23. B. A. Bushaw, "Kinetic Analysis of Laser Induced Phosphorescence in Uranyl Phosphate for Improved Analytical Measurements," Proceedings of the Twenty-Sixth ORNL-DOE Conference on Analytical Chemistry in Energy Technology, Elsevier Publishers, Amsterdam, 1983.

24. R. Brina and A. G. Miller, "Direct Detection of Trace Levels of Uranium by LaserInduced Kinetic Phosphorimetry," Anal. Chem. 64, 1413 (1992).

25. American Society for Testing and Materials, Annual Book of ASTM Methods, 11.02, 425 (1992). 
26. D. W. Medley, R. L. Kathren, and A. G. Miller, "Diurnal Urinary Volume and Uranium Output in Uranium Workers and Unexposed Controls," Health Phys. 67, 122 (1994).

27. L. L. Moore and R. L. Williams, "A Rapid Method for Determining Nanogram Quantities of Uranium in Urine Using the Kinetic Phosphorescence Analyzer," J. Radioanal. and Nucl. Chem. 156, 223 (1992).

28. J. H. Harley, ed., "Radiochemical Determination of Isotopic Uranium, Method E-U-04," HASL-300, Environmental Measurements Laboratory, New York, 1979.

29. U.S. Environmental Protection Agency, Prescribed Procedures for Radiaactivity in Drinking Water, EPA-600/4-80-032, Environmental Monitoring and Support Laboratory, Cincinnati, OH, 1980.

30. J. E. Gindler, The Radiochemistry of Uranium, NAS-NS-3050, National Academy of Sciences, Washington, 1962.

31. C. W. Sill and R. L. Williams, "Preparation of Actinides for Spectrometry without Electrodeposition," Anal. Chem. 53, 412 (1981).

32. H. H. Kramer, V. J. Molinski, and H. W. Nass, "Urinalysis for Uranium-235 and Uranium-238 by Neutron Activation Analysis," Health Phys. 13, 27 (1967).

33. V. A. Manchuk et al., "Neutron-Activation Determination of Uranium-238 and Thorium-232 in Urine," Radiokhimiya 21, 905 (1979).

34. J. Holzbecher and D. E. Ryan, "Determination of Uranium by Thermal and Epithermal Neutron Activation in Natural Waters and in Human Urine," Anal. Chim. Acta 119, 405 (1980).

35. R. L. Kathren, A. E. Desrosiers, and L. B. Church "Thorium-230 Assay by Epithermal Neutron Activation Analysis," Proc. 5th Cong. Int. Radiat. Prot. Soc. 2, 923 (1980).

36. F. F. Dyer, J. F. Emery, and G. W. Leddicotte, $A$ Comprehensive Study of the Neutron Activation Analysis of Uranium by Delayed-Neutron Counting, ORNL-3352, Oak Ridge National Laboratory, 1962.

37. S. Amiel, "Analytical Applications of Delayed Neutron Emission in Fissionable Elements," Anal. Chem. 34, 1683 (1962). 
38. N. N. Papadopoulos, "Uranium and Short-Lived Nuclide Activation Analysis by Delayed Neutron and Gamma-Spectrum Measurements with a New Versatile Sample Transfer System," J. Radioanal. Chem. 72, 463 (1982).

39. H. M. Ide et al., "Analysis of Uranium in Urine by Delayed Neutrons," Health Phys. 37, 405 (1979).

40. R. J. N. Brits and E. A. Holemans, "Determination of Uranium in Urine by Delayed Neutron Counting," Health Phys. 36, 65 (1979).

41. J. P. Young et al., "Resonance Ionization Spectroscopy," Anal. Chem. 51, 1050A (1979).

42. G. S. Hurst et al., "Resonance Ionization Spectroscopy and One-Atom Detection," Rev. Mod. Phys. 51, 767 (1979).

43. G. S. Hurst, M. H. Naythe, and J. P. Young, "A Demonstration of One-Atom Detection," Appl. Phys. Letter 30, 229 (1977).

44. J. E. Parks et al., "Sputter Initiated Resonance Ionization Spectroscopy for Trace Element Analysis," Proceedings of the Twenty-Sixth ORNL-DOE Conference on Analytical Chemistry in Energy Technology, Elsevier Publishers, Amsterdam, 1983.

45. F. M. Kimock, J. D. Baxter, and N. Winograd, "Ion and Chemisorption Using Low Dose SIMS and Multiphoton Resonance Ionization," Surf. Sci. 124, 141 (1983).

46. N. S. Nogar et al., "Resonance Ionization Mass Spectrometry at Los Alamos National Laboratory," Proceedings of the Twenty-Sixth ORNL-DOE Conference on Analytical Chemistry in Energy Technology, Elsevier Publishers, Amsterdam, 1983.

47. J. D. Fassett, L. J. Moore, and J. C. Travis, "Resonance Ionization Mass Spectrometry of Iron-Quantitative Aspects," Proceedings of the Twenty-Sixth ORNL-DOE Conference on Analytical Chemistry in Energy Technology, Elsevier Publishers, Amsterdam, 1983.

48. J. P. Young and D. L. Donohue, "Ionization Spectra of Neodymium and Samarium by Resonance Ionization Mass Spectrometry," Anal. Chem. 55, 88 (1983).

49. J. E. Parks et al., Bioassay Measurements for Uranium Using Sputter Initiated Resonance Ionization Spectroscopy, NUREG/CR-4419, TI86 900577, U. S. Nuclear Regulatory Commission, Washington, 1986. 
50. E. S. Gladney et al., "Determination of $U$ in Urine: Comparison of ICP-Mass Spectrometry and Delayed Neutron Assay," Health Phys. 57, 171 (1989).

51. Y. Igarashi et al., "Determination of Thorium and Uranium in Biological Samples by Inductively Coupled Plasma Mass Spectrometry Using Internal Standardisation," J. Anal. Atomic Spectrom. 4, 571 (1989). 


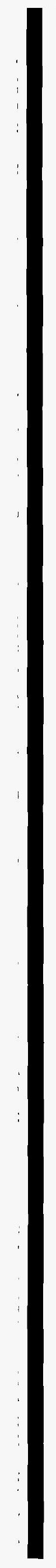




\section{INTERNAL DISTRIBUTION}

1-5. J. S. Bogard

6. R. S. Bogard

7. J. G. Dorsey

8. F. F. Dyer

9. M. Hotchandani

10-11. R. W. Oliver

12. M. M. Reichert

13. J. R. Stokely

14-15. M. Thein
16. G. D. Robbins

17. R. E. Swaja

18. J. W. Wade

19-21. Laboratory Records

22. Laboratory Records - RC

23. Central Research Library

24. ORNL Technical Library, $\mathrm{Y}-12$

25. ORNL Patent Section 26-30. MAD Records Center

\section{EXTERNAL DISTRIBUTION}

31-38. J. R. Johnson, Health Physics Department, Battelle Pacific Northwest Laboratory, P. O. Box 999, Richland, WA 99352

39. T. J. Whitaker, Atom Sciences, Inc., 114 Ridgeway Center, Oak Ridge, TN 37830

40. Office of Assistant Manager, Energy Research and Development, DOE Oak Ridge Operations, P.O. Box 2001, Oak Ridge, TN 37831-8600

41-43. Office of Scientific and Technical Information, U.S. Department of Energy, P.O. Box 62, Oak Ridge, TN 37831 
